\title{
Effect of Pramehamihira taila in the management of Madhumehaja paadadaaha w.s.r to Diabetic sensory neuropathy
}

\author{
Research article
}

\section{Mahalakshmi KM ${ }^{1^{*}}$}

1. Assistant Professor, Department of Panchakarma, JSS Ayurveda Medical College \& Hospital, Mysuru.

\begin{abstract}
Diabetes Mellitus is a metabolic disorder of multiple etiologies. Diabetic neuropathies occur in approximately $50 \%$ of individuals with long standing Diabetes. Diabetic foot is one of the commonest chronic complications of Diabetes. In Ayurveda Samhitha, paadadaaha is explained as samanya purvaroopa of Prameha \& Daaha is also mentioned as samanya upadrava of Prameha. Paadadaaha is said to be caused due to vitiated Vata \& Pitta. Pramehamihira taila has properties such as Vatahara, Pittahara \& daaha prashamana. Hence the present clinical study was carried out to assess the effect of Pramehamihira tail in the management of Madhumehaja paadadaaha w.s.r. to Diabetic sensory neuropathy.

In this study 30 patients with confirmed diagnosis of paadadaaha were subjected to Paadaabhyanga with Pramehamihira taila for 14 days \& assessment of result was done for subjective signs. From statistical analysis, it was evident that, 20 patients $(66 \%)$ showed good response, 10 patients $(44 \%)$ showed moderate response $\&$ none of the patients showed poor or no response. From the present study it can be concluded that the condition paadadaaha can be managed by Paadaabhyanga with Pramehamihira taila.
\end{abstract}

Keywords: Madhum ehaja paadadaaha, Pramehamihira taila, Paadaabhyanga, Diabetic sensory neuropathy.

\section{Introduction:}

Diabetic foot care is as important as the care of Diabetes. It is the most common metabolic disease which is prevalent in every part of the world and is a major public health challenge of 21 st century. It may be accompanied with the presence of progressive Diabetic tissue damage with micro \& macro vascular complications. The distal sensory peripheral neuropathy affects the extremities \& mostly seen in lower limbs in socks \& glove fashion $(1 \& 2)$

In Madhumehaja paadadaaha there is avarana of Vata by the Pitta (3).There is involvement of Vata along with Pitta in producing daaha. So, the Vata \& Pittahara chikitsa has to be adopted. In the samanya upakramas of Vata, snehana is one of the line of treatment and abhyanga is one of the bahya sneha (4).So Pramehamihira which does both Vata \& Pitta shamana $\&$ which is also indicated in daaha was selected (5).

\section{Objectives:}

To evaluate Effect of Pramehamihira taila Paadaabhyanga in the management of Madhumehaja paadadaaha w.s.r to Diabetic sensory neuropathy.

\footnotetext{
*Corresponding Author:
}

\section{Mahalakshmi K M}

Assistant Professor, Department of Panchakarma, JSS Ayurveda Medical College \& Hospital, Mysuru. Phone- 9900979629

E-mail:drmahalakshmi15@gmail.com

\section{Materials \& Methods}

Materials taken for the study was Pramehamihira taila .It was prepared in JSS Ayurveda Pharmacy, Mysuru.

\section{Methods}

Sampling:

30 patients with confirmed diagnosis of Madhumehaja paadadaaha were selected from OPD \& IPD of JSSAMC \& Hospital, Mysuru.

\section{Inclusion criteria:}

- Both male \& female patients were taken for the study.

- Patients between the age group of 30-70 yrs suffering with diabetic mellitus \& presenting with paadadaaha were selected.

- Patients fit to undergo Paadaabhyanga.

- Burning sensation feature of sensory neuropathy with or without the presence of other altered sensation were taken.

\section{Exclusion Criteria:}

- Patients with any other systemic disorders which may interfere in the Course of the treatment of Paadaabhyanga were excluded

- Patients with Trauma, infectious wounds, gangrene and non healing ulcer of foot were excluded

- Mono neuropathies were excluded.

- Neuropathies, secondary to, other than Diabetes were excluded. 


\section{Laboratory investigations}

Blood - Fasting Blood sugar

Post Prandial Blood sugar Glycosylated Hemoglobin (HbA1C)

Urine - Fasting urine sugar

Post Prandial urine sugar

\section{Diagnostic Criteria}

Diabetic mellitus, presenting with burning sensation of the feet is the criteria.

\section{Research design}

It was a single blind clinical study.

\section{Intervention}

All 30 patients were taken for Paadaabhyanga by Pramehamihira taila. 3 steps.

The procedure of Paadaabhyanga was followed in

\section{Purvakarma:}

Cleaning of the paada with sukoshna Jala

\section{Pradhana karma:}

for $48 \mathrm{~min}$

\section{Pashchatkarma:}

Rest for 10 min, washing the paada with Sukoshna Jala, Wiping the paada with soft cotton towel.

Pathya-apathya was advised

This procedure was carried out for 14 days and assessment was done after the treatment i.e. for 1st day, 7 th day, 14 th day, $\&$ for 21 st day, 30 th day $\& 60$ th day of the follow ups.

\section{Assessment criteria}

The cardinal clinical manifestations, symptoms were scored according to the severity and considered as the assessment criteria for the study.

\section{Subjective parameters:}

Short-form McGill Pain Questionnaire

\section{Grading of the parameters:}

The grading was done in the following manner

0 . No burning sensation of the feet-Absent

1. Mild burning sensation-Occasional

2. Moderate burning sensation-Discomforting

3. Severe burning sensation-Hot as on fire

To assess the overall effect of Pramehamihira taila Paadaabhyanga following criteria were taken.

1. Good response - $>50 \%$ of improvement

2. Moderate response - $30 \%$ to $49 \%$ of improvement

3. Poor response $-1 \%$ to $29 \%$ of improvement

4. No response - No improvement

\section{Observations and Results}

It was observed that out of 30 patients $16(53.33 \%)$ were male patients \& 14 (46.66\%). Paada daaha was seen more in the age group of 56-65yrs (56.66\%). Maximum number i.e. 17 Patients $(56.66 \%)$ were vegetarians and 13 patients $(43.33 \%)$ were non vegetarians (mixed). Maximum number i.e. $66.66 \%$ of patients had family history, $10 \%$ of the patients had no family history of Madhumeha \& rest $23.33 \%$ did not know whether they had it or not. Most of them i.e. 27 (90\%) were with Teeksnagni, Samaagni $3.33 \%$ and Vishamaagni $6.66 \%$.The Chronicity of paada daaha was- 18 patients $(60 \%)$ suffered daaha for about $1 \mathrm{~m}$ $6 \mathrm{~m}, 9$ patients $(30 \%)$ for $6 \mathrm{~m}-1 \& 3$ patients $(10 \%)$ more than $1 \mathrm{yr}$.

Table 1: Showing the Statistical Results for - during days of treatment.

\begin{tabular}{|l|l|l|l|l|l|l|l|}
\hline SL & DAYS & MEAN & SD & SE & t-VALUE & p-VALUE & REMARKS \\
NO & & & & & & \\
\hline 1 & $1^{\text {st }}$ & 2.37 & 0.556 & 0.102 & 17.696 & $<0.001$ & HS \\
& $7^{\text {th }}$ & 1.33 & 0.479 & 0.088 & & & \\
\hline 2. & $1^{\text {st }}$ & 2.37 & 0.556 & 0.102 & 22.722 & $<0.001$ & HS \\
\hline 3. & $14^{\text {th }}$ & 0.33 & 0.479 & 0.088 & & & HS \\
& $7^{\text {th }}$ & 1.33 & 0.479 & 0.088 & 20.857 & $<0.001$ & \\
\hline
\end{tabular}

HS - Highly Significant

Table 2: Showing the Statistical Results for last day of treatment \& successive follow ups.

\begin{tabular}{|l|l|l|l|l|l|l|l|}
\hline SL NO & DAYS & MEAN & SD & SE & t-VALUE & p-VALUE & REMARKS \\
\hline 1 & $14^{\text {th }}$ & 0.33 & 0.479 & 0.088 & 5.14 & $<0.001$ & HS \\
& $21^{\text {st }}$ & 0.43 & 0.504 & 0.092 & & & \\
\hline 2 & $14^{\text {th }}$ & 0.33 & 0.479 & 0.088 & 6.14 & $<0.001$ & HS \\
& $30^{\text {th }}$ & 0.43 & 0.504 & 0.092 & & & \\
\hline 3 & $14^{\text {th }}$ & 0.33 & 0.479 & 0.088 & 1.14 & $<0.264$ & NS \\
& $60^{\text {th }}$ & 0.87 & 0.434 & 0.079 & & & \\
\hline
\end{tabular}

HS - Highly Significant 
Table 3: Showing the Statistical Results for first day of treatment and successive follow-up days.

\begin{tabular}{|l|c|c|l|l|l|l|l|}
\hline SL NO & DAYS & MEAN & \multicolumn{1}{|c|}{ \pm SD } & SE & t-VALUE & p-VALUE & REMARKS \\
\hline 1 & 1 st 21st & 2.370 .43 & 0.556 & 0.102 & 16.554 & $<0.001$ & HS \\
& & & 0.506 & 0.092 & & & \\
\hline 2 & 1 st 30th & 2.370 .43 & 0.556 & 0.102 & 16.554 & $<0.001$ & HS \\
& & & 0.504 & 0.092 & & & \\
\hline 3 & 1 st 60th & 2.370 .87 & 0.556 & 0.102 & 13.047 & $<0.001$ & HS \\
\hline
\end{tabular}

HS - Highly Significant

Table 4: Showing the Overall assessment

\begin{tabular}{|l|l|l|l|}
\hline \multicolumn{1}{|c|}{ Sl.No } & \multicolumn{1}{c|}{ Assessment } & \multicolumn{1}{c|}{ No of Patients } & \multicolumn{1}{c|}{ Percentage } \\
\hline 1 & Good response & 20 & $66 \%$ \\
\hline 2 & Moderate Response & 10 & $44 \%$ \\
\hline 3 & Poor Response & 0 & 0 \\
\hline 4 & No Response & 0 & 0 \\
\hline
\end{tabular}

Graph 1: Showing the overall assessment

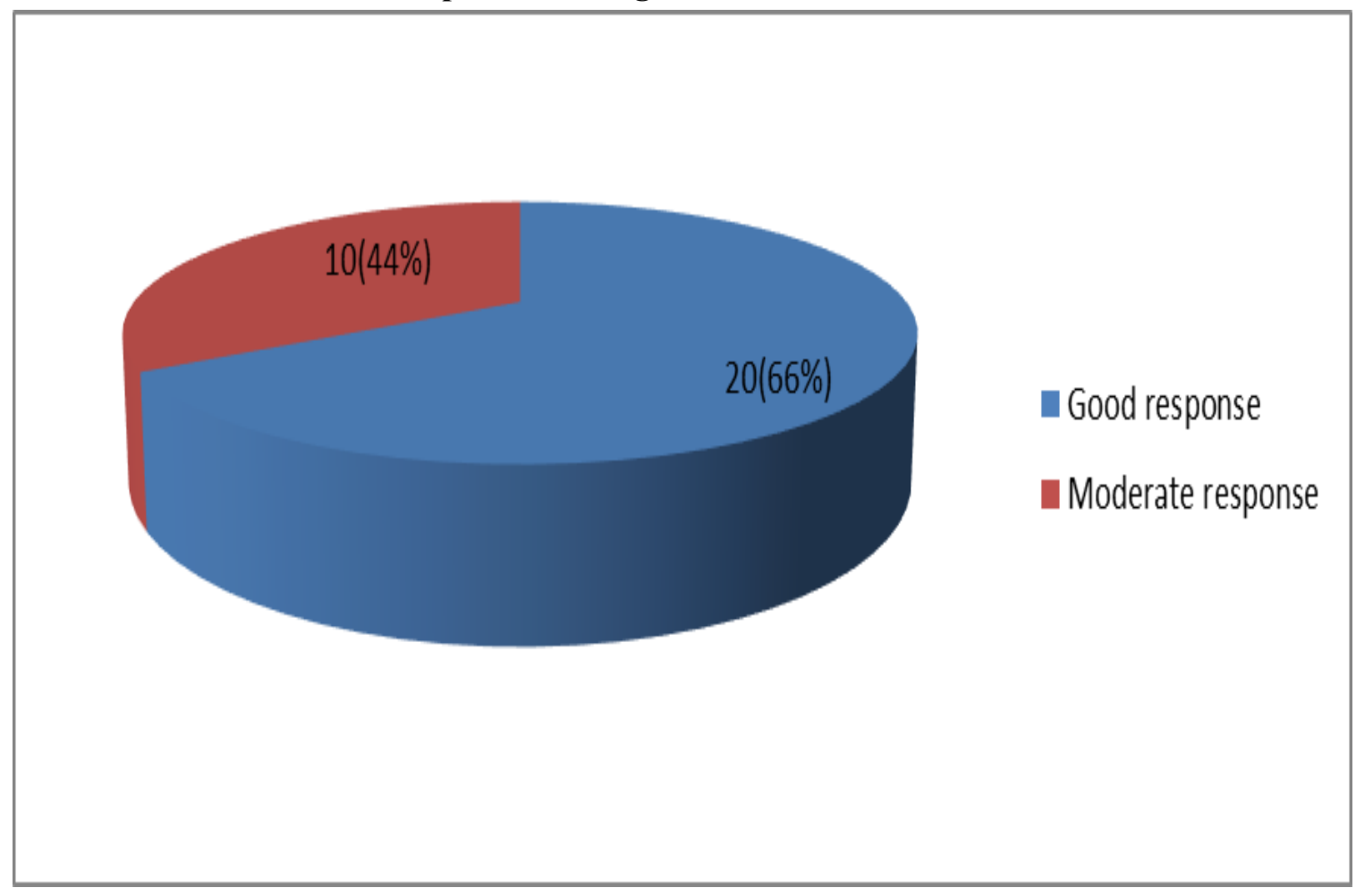

\section{Discussion}

\section{Discussion on Paadaabhyanga}

The effect of abhyanga can be assumed in two ways i.e. effect of physical manipulations and the effect of the drug in the medicated oil (6)

There are 3 factors which govern the permeability of the skin-

The skin itself -The vehicle which affects the transfer. The substance which penetrate, permeate or is absorbed. Anything hot or warm applied to the skin will immediately cause capillary dilatation. Same phenomenon applies when abhyanga is carried out. Fat enter through the dilated capillaries can easily be absorbed into the system.

The lack of blood circulation is one of the reasons for impaired sensation as nerves will be deprived of oxygen \& nutrition .The procedure, heat is produced which causes vasodilatation \& circulation to the part ,the local vasodilatation occurs relaxation of the nerves takes place. 


\section{Discussion on procedure}

Vayu dominates in the sparshanendriya i.e. tactile sensory organ Vata is the main dosha causing daaha Abhyanga is one of the best upakarma for Vataja roga (7). Oil used in abhyanga reaches different dhatus, if applied for the speculated time. The veerya of the drugs in abhyanga, parisheka, avagaha and lepa are absorbed into the skin and then digested by Agni (Bhrajaka Pitta)(8). So this taila has given moderate improvement. This could have given major improvement if, Paadaabhyanga was undertaken as foot care measure, as a routine every day.

\section{Discussion on Formulation}

The drugs used in this taila are Dahaprashamana, Pittahara, Vatahara.A combined action of tila taila which is Vatahara \& dravyas which are Pittahara can be ascertained.So action is on Vata \& Pitta involved in samprapti of madhumehaja daaha.(9).

\section{Discussion on results}

In the study all of them had severe - moderate paada daaha on the day one, which came to mild after seventh day $\&$ nil on the 14 th day. Although $80 \%$ of them had reoccurrence of daaha on the 60th day of follow up, but the severity was very less compared to the first day. Along with the good results in reduction of Padadaaha, the additional benefits such as kharatvahara, rukshatva nasha,nidrakara in $80 \%$ of the patients was achieved.

\section{Conclusion}

Prevalence of Madhumehaja paadadaaha was more in the age group 46-55 years. Madhumehaja paadadaaha can be effectively paralleled with 'diabetic sensory neuropathy.'Involvement of avarana of Vata by Pitta is invariable in the samprapthi of madumehaja paadadaaha.The taila which is processed with vatahara \& pitta hara drugs are helpful in the samprapthi vighatana of Madhumehaja paadadaaha. So this formulation is helpful in relieving the symptoms of daaha through Paadaabhyanga, as it is one of the best upakarma indicated for Vata dosha.

'If you protect your feet they will stand up for you' The Diabetic foot care is as important as the care of Diabetes. If diagnosed \& treated earlier further foot complication $\&$ amputation can be avoided.

\section{References}

1. Parveen Kumar \& Michael Clark, Kumar \& Clack's clinical medicine $7^{\text {th }}$ edition, $19^{\text {th }}$ chap,page no 1056 .

2. YP Munjal,API textbook of Medicine, $9^{\text {th }}$ edition, $19^{\text {th }}$ chap,page no 387.

3. Charaka samhita by Agnivesha \& Drudabala with the Ayurveda Deepika commentary of Chakrapani Datta edited by Vaidya Jadavji Trikamji Acharya Choukamba orientalia Varanasi reprint 2011,chikitsa, $28^{\text {th }}$ chap,page no 619.

4. Charaka samhita by Agnivesha \& Drudabala with the Ayurveda Deepika commentary of Chakrapani Datta edited by Vaidya Jadavji Trikamji Acharya Choukamba orientalia Varanasi reprint 2011,chikitsa sthana, $28^{\text {th }}$ chap,page no 104 .

5. Bhaishajya Ratnavalli Vidhyothini Hindi Vyakhya Vimana Parishista Samhitha, Vyakhyakhara Kaviraja Sri Ambikadatta Shastri Ayurvedacharya Sampadaka Sri Rajeshwaradatta Shastri Ayurvdacharya published by Chakambha SamskruthaSamsthana,Varnasi 10th Edition Chikitasa page 421 Shloka no 228-236

6. Vasant C. Patil, Principles \& practice of Panchakarma, $3^{\text {rd }}$ edition,page no 179 .

7. Charaka samhita by Agnivesha \& Drudabala with the Ayurveda Deepika commentary of Chakrapani Datta edited by Vaidya Jadavji Trikamji Acharya Choukamba orientalia Varanasi reprint 2011,sutra sthana, $5^{\text {th }}$ chap,page no 42 .

8. Shuhusruta Samhita of Shusruta with the Nibanda Sangraha commentary of Sri Dalhanacharya and the Nyayachandrika Panjika of Vaidya Jadavji Trikamji Acharya - Chaukamba Subharathi Prakashan Varanasi reprint 2012 , Chikitsa sthana, $24^{\text {th }}$ chap,page no 488.

9. Bhaishajya Ratnavalli Vidhyothini Hindi Vyakhya Vimana Parishista Samhitha, Vyakhyakhara Kaviraja Sri Ambikadatta Shastri Ayurvedacharya Sampadaka Sri Rajeshwaradatta Shastri Ayurvdacharya published by Chakambha SamskruthaSamsthana,Varnasi 10th Edition Chikitasa page 421 Shloka no 228-236.

10.Satorhar R S, Bhandar SD, Nirmala N rege, Pharmacology and pharmacotherapeutics, $21^{\text {st }}$ edition.

11.Robert M Herndan, Handbook of Nuerologic rating scales, $11^{\text {th }}$ edition. 